\title{
Onkolitički virusi
}

1 Ines Poljak

2 Petra Korać

1 Zdravstveno veleučilište Zagreb

2 Zavod za molekularnu biologiju, Biološki odsjek, Prirodoslovno-matematički fakultet, Sveučilište u Zagrebu

\section{Sažetak}

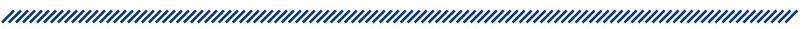

Maligni tumori danas su najčešći uzročnici smrtnosti u ljudi. Nakupljanje mutacija u stanicama uzrokuje nekontroliranu diobu stanica, kao i sprječavanje njihove programirane smrti, što dovodi do neoplastičnih promjena. Nakuplja se tumorska masa koja izbjegava imunosni odgovor domaćina. Moderan pristup terapiji malignih tumora, koji je još uvijek u istraživačkoj fazi, temelji se na primjeni bakterija i/ili virusa koji su genetički modificirani. Njima se potiče kemotaksijski učinak ili nastanak receptora koje će prepoznati imunosni sustav domaćina kako bi se potaknulo efektorski dio obrambenog sustava organizma na uništavanje tumorske mase. U ovom radu dan je sažet prikaz najnovijih metoda navedenog područja.
Ključne riječi: genetičko inženjerstvo, onkolitički virusi, maligni tumori

Datum primitka: 25.08.2018.

Datum prihvaćanja: 07.10.2018.

DOI: $10.24141 / 1 / 4 / 2 / 12$

\section{Adresa za dopisivanje:}

izv. prof. dr. sc. Petra Korać

Zavod za molekularnu biologiju, Biološki odsjek, Prirodoslovno-matematički fakultet, Horvatovac 102A, Zagreb

faks: +38514606286

tel.: +38514606278

e-pošta: petra.korac@biol.pmf.hr 


\section{Uvod}

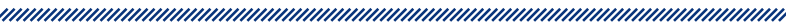

Nakupljanje stanica koje čine tkivo bez fiziološke funkcije naziva se tumor ili neoplazma. Jedno je od temeljnih svojstava tumora klonalnost, nastanak iz jedne stanice koja počinje proliferirati. Naknadnim nakupljanjem mutacija različite populacije tumorskih stanica stječu različita svojstva, što tumor čini heterogenim. Tumori koji imaju potencijal širenja po organizmu u kojem su nastali smatraju se malignima. Maligni tumori jedan su od najvećih uzročnika morbiditeta i mortaliteta u današnjem svijetu. Prema podacima svjetske zdravstvene organizacije (WHO, engl. World Health Organisation) za 2012. godinu, od 14 milijuna novih slučajeva tumora smrtni je ishod zabilježen za 8,2 milijuna. ${ }^{1}$

Uzroci malignih transformacija povezuju se s vanjskim faktorima kao što su mutageni, odnosno karcinogeni, pogreškama u mehanizmima same stanice poput greške u replikaciji i sl., a vrlo su važni i biološki uzročnici promjena koji sudjeluju u nastanku tumora kao što su npr. mikotoksini ili neki mikroorganizmi (npr. bakterija Helicobacter pylori, Epstein-Barrov virus itd.). ${ }^{2}$

Glavna su svojstva tumorskih stanica promijenjeni mehanizmi koji kontroliraju staničnu proliferaciju, diferencijaciju i preživljavanje. Uzrokuju neosjetljivost tumorskih stanica na inhibiciju ovisnu o gustoći ili kontaktnu inhibiciju, nedostatak receptora na tumorskim stanicama za izvanstanične faktore rasta (autokrina signalizacija), smanjenu produkciju adhezijskih molekula, kao i lučenje proteaza i angiogenetskih faktora. ${ }^{2}$

Uz to, tumorske stanice tijekom razvoja tumora eksprimiraju tumorske antigene - antigene koji nisu prisutni u stanicama iz kojih se tumor razvio ili u razvojnom stadiju stanica iz kojih je nastao tumor. Tumorski se markeri T-limfocitima prezentiraju vezani na molekule razreda MHC-I ili MHC-II. Dvije su vrste tumorskih antigena: antigeni specifični za tumor (TSA, engl. tumor-specific antigens) $i$ antigeni pridruženi tumoru (TAA, engl. tumorassociated antigens). ${ }^{3}$ Faktori koji izazivaju ekspresiju tumorskih antigena su kemijska i fizička sredstva, virusi, onkofetusni antigeni, faktori rasta, receptori za faktore rasta i proteini kodirani onkogenima. ${ }^{4}$ Imunosne reakcije domaćinskog organizma specifične za tumor vrlo su različite te ovisno o tipu tumora mogu biti imunosna obrana od tumora, imunosni nadzor nad stanicama tumora, ali i neprepoznavanje tumora i posljedično njegovo izbjegavanje imunosnoj obrani domaćina. ${ }^{3}$ Najvažni- ju ulogu u imunosnoj obrani od tumora imaju stanice imunosnog sustava - imunosni sustav domaćina prepoznaje tumor kao strano tkivo te započinje imunosnu obranu. Stanice koje u najvećoj mjeri stvaraju imunosni odgovor specifičan za tumor jesu citotoksični T-limfociti, NK-stanice i makrofagi/monociti. ${ }^{5}$ lako je mehanizam tumora za izbjegavanje imunosnog odgovora vrlo složen i dobro reguliran, njegovi su detalji još uvijek nepoznati. Ipak, nekoliko je hipoteza kojima se taj mehanizam nastoji objasniti: 1) slaba imunogenost tumorskih antigena ili nedostatak molekula MHC-I na tumorskim stanicama, što omogućuje tumoru da bude nezamijećen; 2) imunoselekcija, odnosno prevladavanje tumorskih stanica otpornih na obranu domaćina ili „ispravljanje tumora"; 3) antigenska modulacija, reverzibilna promjena nestanka ekspresije antigena $s$ membrane stanica; 4) nedostatak kostimulatornih molekula ili molekula razreda MHC-II potrebnih za aktivaciju T-limfocita (ako nedostaje jedan od dva signala, umjesto do aktivacije T-limfocita može doći do anergije); 5) prekomjerna ekspresija antigena tumorskih stanica u odnosu na normalne (zbog neprestanog otpuštanja antigena oko tumora se može stvoriti zaštitni sloj); 6) teorija „bijega" kroz imunosnu obranu, do kojeg dolazi s obzirom na početno premali broj tumorskih stanica koje mogu izazvati imunoreakciju, a kada je količina stanica, tj. antigena dovoljna, tumor je već razvijen; 7) imunosna nereaktivnost, javlja se kao imunotolerancija u neonatalno doba vertikalno prenesena onkogenim virusima $\mathrm{i}$ imunodeficijencija koja može biti prirodna, jatrogena ili uzrokovana tvarima koje izlučuju tumori; 8) teorija faktora blokade, koja se javlja u humoralnoj imunosti kada serum nositelja progresivnoga tumora može in vitro blokirati staničnu citotoksičnost, a serum organizma s regresivnim tumorom nema to djelovanje. ${ }^{3}$ Nove terapije stoga imaju cilj smanjiti sposobnost tumora za izbjegavanje imunosnog odgovora domaćina i omogućiti imunosnom sustavu prepoznavanje i uništenje tumorskih stanica. Jedan je od načina koji se sve više istražuje modifikacija mikroorganizama primjenom metoda genetičkoga inženjerstva, posebice stvaranja onkolitičkih virusa.

\section{Onkolitički virusi}

Onkolitički virusi su virusi koji se umnažaju u tumorskim stanicama, ubijaju ih i šire se među njima a da ne oštećuju ili inficiraju netumorske stanice. ${ }^{6}$

Tijekom prvih kliničkih istraživanja primjene onkolitičkih virusa 1949. godine, 22 pacijenta s dijagnozom Hodgkinova limfoma primila su nemodificirani virus 
hepatitisa B koji se može replicirati u normalnim stanicama. Četrnaest ispitanika razvilo je virusni hepatitis, a jedan je umro tijekom probnog perioda zbog posljedica nasumičnog umetanja virusa u genom. Sljedeći je korak bio stvaranje virusa koji inficiraju samo tumorske stanice. Godine 1990. razvojem genetičkog inženjerstva koje je omogućilo virusne modifikacije kako bi zdrave stanice ostale očuvane mogao se ostvariti i taj korak. ${ }^{7}$

Za tumorske terapije danas se stvaraju modificirani virusi koji se ne mogu replicirati u netumorskim stanicama. ${ }^{7}$

Znatan problem kod ovog pristupa liječenja i dalje predstavlja reakcija domaćina na onkolitičke viruse. Većina virusa koji su do sada upotrebljavani poznati su ljudskom tijelu te nedugo nakon unosa dolazi do njihova prepoznavanja od strane imunosnog sustava i neutralizacije antitijelima. ${ }^{8}$ Velik broj biotehnoloških tvrtki bavi se modificiranjem virusa za koje je poznato da su patogeni za ljude, ali postoje i istraživanja provedena na virusima za koje nije utvrđeno da uzrokuju infekcije u ljudi. Npr. Maraba vesiculovirus je rabdovirus koji nema poznati patološki učinak u ljudi, već se u normalnim stanicama vrlo brzo eliminira s pomoću imunosnog sustava putem interferonskog signaliziranja, što bi potencijalno moglo imati važne rezultate prilikom selektivnosti za tumorske stanice. ${ }^{8}$

Neki od danas razvijenih lijekova koji se temelje na onkolitičkim virusima su: ${ }^{8}$

\section{Rigvir (Riga-virus)}

Virus koji se može primijeniti u terapiji melanoma, a temelji se na nemodificiranim virusima. Godine 2004. ova je terapija melanoma dozvoljena u Latviji, ali ne i u Europskoj uniji. Rigvir sadrži živi nepatološki nemodificiran virus ECHO-7. ${ }^{9}$ To je onkotropni i onkolitički virus koji selektivno pronalazi i inficira samo tumorske stanice.

\section{Oncorine (H101)}

Lijek koji je proizvela kompanija Sunway Biotech u Kini. U Kini mu je dozvoljena upotreba 2005. godine. Riječ je o modificiranom adenovirusu koji se primjenjuje kod terapije tumora glave i vrata. Selektivnost virusa za tumorske stanice uzrokovana je specifičnim delecijama u virusnom genomu. Nedostaju mu geni E3 (koji mogu uzrokovati apoptozu domaćinske stanice) kao i regija gena $E 1 B$ koja kodira polipeptid molekulske mase 55kD (polipeptid E1B55K štiti inficiranu stanicu od posljedica djelovanja tumorskog supresora p53 divljeg tipa, kao što je poticanje apoptoze, mehanizmom koji još uvijek nije u potpunosti razjašnjen). Navedene modifikacije virusnog genoma učinjene na temelju poznavanja interakcija virusnih proteina i staničnog tumorskog supresora p53 onemogućuju virusnu replikaciju u netumorskim stanicama, tj. stanicama koje proizvode funkcionalan protein $\mathrm{p} 53$, ali je potiču u tumorskim stanicama kojima nedostaje p53. ${ }^{10}$

\section{Imlygic (T - VEC)}

Modificirani virus Herpes simplex tipa 1 stigao je 2015. godine na američko tržište, ali je dozvoljen samo kod terapije tumorskih lezija melanoma koje nije moguće odstraniti kirurški. Slabe su točke ovog pristupa potreba direktnog unošenja u tumorsku masu i česta neutralizacija virusa od strane imunosnog sustava čovjeka. ${ }^{11}$

Osim nekoliko postojećih lijekova kojima je temelj onkolitički virus, u tijeku je i velik broj istraživanja kojima se nastoji povećati specifičnost i učinkovitost terapija temeljenih na opisanom pristupu.

Najpoznatija su istraživanja rekombiniranog onkolitičkog poliovirusa PVS-RIPO, kao i istraživanja koja primjenjuju viruse kao cjepiva ili kao temelj genskih terapija.

\section{Rekombinirani onkolitički poliovirus PVS-RIPO}

U centru za tumore mozga Preston Robert Tisch genetičkim je inženjeringom dobiven onkolitički poliovirus nazvan PVS-RIPO, čije istraživanje je objavljeno 2012. godine, a klinička testiranja njegove uporabe započela su 2015. godine. Riječ je o rekombiniranom, atenuiranom i nepatogenom poliovirusu u kombinaciji s dijelom rinovirusa koji ima mogućnost umanjivanja tumorske aktivnosti. ${ }^{12} \mathrm{Za}$ ovu su inovaciju zaslužni Matthias Gromeier i Gordana Vlahović. PVS-RIPO je korišten kod terapije tumora mozga.

Poliovirus pripada rodu enterovirusa, porodici Picornaviridae. ${ }^{13}$ Malen je virus ( $\left.28-30 \mathrm{~nm}\right) \mathrm{s}$ jednolančanom molekulom RNA koji nema ovojnicu, može se inaktivirati inkubacijom na $55{ }^{\circ} \mathrm{C}$ tijekom 30 minuta. ${ }^{13}$ Infekcija je poliovirusom akutna, virus inficira središnji živčani sustav i uzrokuje bolest poliomijelitis, tj. dječju paralizu. ${ }^{13}$ Virus ulazi kroz usta, a razmnožava se u gastrointestinalnom traktu. Postoji mogućnost proboja virusa do središnjega živčanog sustava preko aksona perifernih živaca, a ondje se dalje umnožava u donjim motoričkim neuronima. ${ }^{12}$ Period inkubacije obično traje od 7 do 14 dana. ${ }^{13}$ 
Rhinovirus pripada rodu enterovirusa, porodici Picornaviridae. ${ }^{13}$ Izolirano je oko 150 tipova ovoga virusa koji dijele $70 \%$ genoma. ${ }^{13}$ Kao i poliovirusi, oni su maleni virusi $(28-30 \mathrm{~nm}) \mathrm{s}$ jednolančanom molekulom RNA i bez ovojnice. ${ }^{13}$ Uzrokuju običnu prehladu, a nastanjuju gornje dišne putove. Nestabilni su na pH-vrijednosti 5,0 - 6,0, a potpuna inaktivacija se događa pri $\mathrm{pH}$-vrijednosti $3,0 .{ }^{13}$

Mehanizam rada rekombiniranog virusa PVS-RIPO ciljano je zaražavanje i ubijanje stanica tumora mozga a da pritom ne djeluje na normalne stanice. ${ }^{12}$ PVS-RIPO oralni je poliovirus Sabin tipa 1 u kojem je unutarnja ribosomska ulazna jedinica (IRES, engl. internal ribosome entry site) zamijenjena onom iz ljudskog rinovirusa tipa 2. koji ima potencijalnu antineoplastičnu aktivnost. ${ }^{12}$ Receptor CD155 koji virus upotrebljavaj za ulazak u stanicu nalazi se na gotovo svim vrstama solidnih tumora, dendritičkih stanica, makrofaga i ostalih imunosnih stanica. Infekcija imunosnih stanica virusom PVS-RIPO olakšava poticanje antitumorskoga imunosnog odgovora. ${ }^{12}$ Za razliku od drugih onkolitičkih virusa koji uništavaju dendritičke stanice, PVS-RIPO ih stimulira na pojačanu aktivnost i imunosni odgovor. ${ }^{12}$ PVS-RIPO ubija stanice malignoga tumora, ali ne i normalne stanice, jer se veže samo na receptore prisutne na malignim stanicama. Jedini je poliovirus koji se ne uklanja mehanizmom potaknutim interferonom tipa 1. Uklanjanje virusa potaknuto interferonom tipa 1 ovi virusi inače potiču..$^{12}$ Testiranje je prvo provedeno na primatima, a potom i na pacijentima i rezultati su pokazali da nije bilo uništenja neurona, a PVSRIPO nije pokazao mogućnost transformacije u divlji tip poliovirusa koji uzrokuje poliomijelitis. ${ }^{12}$

PVS-RIPO unosi se direktno u područje tumora, odnosno u mozak. Cilja se glioblastom metodom CED (engl. convection-enhanced delivery) koja prolazi krvno-moždanu barijeru te smanjuje ukupnu toksičnost. ${ }^{12}$ Manje od $5 \%$ volumena tumora mora biti zaraženo kako bi se postigla visoka koncentracija virusa. ${ }^{12}$ Osim što nakon ulaska u stanicu tumora PVS-RIPO uništava tu stanicu, pomaže i imunosnoj obrani jer ljudski imunosni sustav prepoznaje stanice zaražene virusom na temelju receptora nekarakterističnih za zdrave stanice istoga tipa. ${ }^{11}$ S obzirom na to da PVS-RIPO zaražava samo tumorske stanice, samo one eksprimiraju membranske receptore koje prepoznaje i na koje djeluje imunosni sustav domaćina, dok netumorske stanice ostaju neoštećene. ${ }^{12}$

Trenutačno se provode istraživanja koja bi trebala prilagoditi PVS-RIPO za terapiju glioblastoma u odraslih, tumora mozga u djece i tumora koji nastaju iz drugih tipova stanica, kao što su melanom te tumori gušterače i prostate. ${ }^{12}$

\section{Antitumorska vakcinacija}

Pretpostavlja se da rekombinirani citomegalovirus (CMV) može poslužiti kao vektor za indukciju imunosnog odgovora kod tumora posredovanog citotoksičnim T-limfocitima te se tako s pomoću njega pokušava stvoriti antitumorsko cjepivo.

Citomegalovirus (CMV) je virus iz porodice Herpesviridae koji može uzrokovati različite bolesti, ali i latentne infekcije, pri čemu često može i doživotno opstati u pojedinim stanicama/organima. ${ }^{14}$ Često je prisutan kao patogen u imunokompromitiranih ljudi (npr. kod ljudi oboljelih od imunosupresivnih bolesti ili kod transplantiranih pacijenata). ${ }^{14} \mathrm{CMV}$ je u latentnom stanju prisutan u mononuklearnim leukocitima, stanicama bubrega i srca. Reaktivacija virusa iz latentnog stanja događa se tijekom imunosupresije ili alogene stimulacije (stimulacije imunosnog odgovora domaćina na stanice unesene transfuzijom ili transplantacijom) ${ }^{14}$ CMV se umnožava u jezgri fibroblasta i makrofaga. Virus se širi većinom preko zaraženih stanica, a može se širiti i transplantacijom organa i transfuzijom. ${ }^{14}$ Vrijeme inkubacije u staničnoj kulturi je 4 do 6 tjedana, a može se inaktivirati toplinom, otopinama niskih pH-vrijednosti, djelovanjem etera, izlaganjem UV zračenju te opetovanim zamrzavanjem i odmrzavanjem. ${ }^{14}$

S obzirom na to da CMV u domaćinu najčešće opstaje u latentnom obliku s periodima reaktivacije, može doći do memorijske upale uzrokovane citotoksičnim T-limfocitima karakteriziranima visokom ekspresijom receptora KLRG1. ${ }^{15} \mathrm{CMV}$ ima veliki genom s nekoliko ključnih gena koji mu pomažu izbjeći imunosni odgovor domaćina. ${ }^{15} \mathrm{Ti}$ geni nisu potrebni za rast i replikaciju virusa pa ih je genetičkim inženjeringom moguće zamijeniti drugim genima. Trenutačna istraživanja bave se ligandom ULBP2 za receptor NKG2D. Budući da je istraživanje provedeno na miševima, na mjesto mišjeg m152 ubačen je RAE-1 $\gamma$ (mišji homolog ljudskog ULBP2) te je kreiran mišji CMV (MCMV). ${ }^{15}$ Mišji m152 inhibira razvoj i funkciju endoplazmatskog retikuluma i izlaganje receptora (NKG2D) na površinu pa ga citotoksični T-limfocit ne mogu prepoznati. ${ }^{15}$ Zamjenom m152 proteinom RAE- $1 \gamma$ dolazi do stvaranja liganda za receptor NKG2D.

Primjenom mišjeg modela $u$ istraživanjima melanoma ljudi pokazano je da vektor RAE-1 $\gamma$ MCMV ima veliku sposobnost odgode i/ili sprječavanje rasta stanica melanoma. ${ }^{14}$ Budući da je RAE- $1 \gamma$ homolog ljudskom ligandu ULBP2, očekuje se da će djelovati i na ljudskim tumorskim stanicama, što se trenutačno i istražuje.

lako je glavni cilj tumorske imunizacije pokretanje imunosnog odgovora domaćina kako bi se eliminirale 
transformirane stanice, također omogućuje dugoročnu prevenciju od recidivirajućih tumora. Zaštitno svojstvo citotoksičnih T-limfocita specifičnih za tumor induciranih vektorom RAE-1MCMV zadržava se tijekom čitavog života bez potrebe za revakcinacijom. ${ }^{15}$

Osim kao profilaksa, vakcinacija protiv tumora pokazuje i odlična svojstva za terapiju već formiranih tumora. ${ }^{15}$

\section{Genska terapija temeljena na modificiranim virusima}

Istraživanje kojim je stvoren onkolitički adenovirus visoke selektivnosti za tumorske stanice provedeno je u Barceloni 2015. godine. Adenovirusi mogu inficirati velik broj organa, što ih čini pogodnima za istraživanje terapije solidnih tumora. Terapijski učinak postiže se modificiranjem genoma adenovirusa kako bi virus prepoznao ekspresiju specifičnih proteina na tumorskim stanicama. ${ }^{16}$

Adenovirusi djeluju litički na stanice prirodnoga domaćina, ali u prijenosnom domaćinu mogu dovesti do transformacije. Transformacija uzrokovana adenovirusima nastaje zbog ekspresije dvaju gena ranoga područja $E 1 A$ i $E 1 B$, nužnih za replikaciju virusa u stanicama prirodnoga domaćina. ${ }^{13}$ Ovi transformirajući proteini inaktiviraju tumorske supresore, proteine Rb i p53: E1A se veže za $\mathrm{Rb}$, a E1B za p53. ${ }^{13}$ Izazivaju respiratorne infekcije u djece i odraslih, ali od adenovirusnih infekcija najviše obolijevaju djeca do 4 . godine života. Virus se prenosi aerosolom u svim dobnim skupinama, a kod djece i fekalno-oralnim načinom. ${ }^{13}$ Poslije svake preboljene infekcije adenovirusom stvaraju se zaštitna antitijela, ali je imunitet za virus nepotpun. Period inkubacije za adenovirusne infekcije najčešće traje 7 do 8 dana. ${ }^{13}$ Inaktivacija se postiže izlaganjem virusa visokim temperaturama te se pri $56^{\circ} \mathrm{C}$ uništava infektivnost u roku od 10 minuta. ${ }^{13}$

Dosadašnjim istraživanjima usmjerenima na primjenu virusa u terapijske antitumorske svrhe omogućeno je da virus ne djeluje u normalnim stanicama, ali je aktivan u tumorskima. ${ }^{16}$ Nova metoda genetičkog inženjeringa primjenjuje mikroRNA (miRNA) specifičnu za određeno tkivo. ${ }^{17}$ Jedan od mehanizama regulacije translacije specifičnih subpopulacija RNA je pomoću cis-elemenata u 3' netranslantirajućoj regiji kao što su citoplazmatski poliadenilacijski elementi koji su povezani s porodicom proteina CPEB (engl. cytoplasmic polyadenylation element binding proteins). ${ }^{16}$ Porodica CPEB sastoji se od četiri proteina (CPEB1-4) koji prepoznaju RNA preko uzastopnih ponavljanja smještenih na C-kraju. ${ }^{16}$ Također, reguliraju ekspresiju velikog broja gena te omogućuju popravke u zdravim stanicama. Potporodice CPEB1 i CPEB2-4 reguliraju funkcije mikro RNA; prepoznaju slične cis-elemente, ali s drukčijim afinitetom. ${ }^{16}$

Proteini CPEB mogu se povezati s regulacijom citoplazmatske poliadenilacije u somatskim i tumorskim stanicama. Neuravnoteženost ekspresije proteina CPEB sudjeluje u transformaciji normalne u tumorsku stanicu. ${ }^{16}$ Dosadašnja su istraživanja stoga koristila neuravnoteženost ekspresije proteina CPEB1, čija je ekspresija vidljiva u normalnim stanicama, ali se ne pojavljuje u tumorskim stanicama, i proteina CPEB4 čija se visoka ekspresija javlja u tumorskim stanicama. Visoka ekspresija proteina CPEB4 povezana je s rastom tumora, angiogenezom i preživljavanjem kod duktalnog adenokarcinoma gušterače i glioblastoma, a povezana je i s nastankom i razvojem karcinoma debelog crijeva. ${ }^{17}$ Budući da se CPEB4 eksprimira kod više vrsta malignih tumora, njegovom je primjenom moguće pokriti širi opseg onkoselektivnosti i potaknuti uništenje više vrsta tumorskih stanica. ${ }^{16}$

Genetičkim inženjeringom modificirana je specifična sekvencija CPE koja aktivira translaciju u tumorskim stanicama, ali zaustavlja translaciju u netransformiranim stanicama. ${ }^{17}$ Daljnjom modifikacijom genoma adenovirusa umetnuta je sekvencija koja regulira ekspresiju E1A preko proteina CPEB. Destabilizacija proteina CPE s c-myc mikro RNA u netransformiranim stanicama povezana je s citoplazmatskom deadenilacijom. Mjerenje poliA-repa u različitim transkriptima E1A je pokazalo da mRNA E1A-cB1 čija je ekspresija posredovana CPE destabilizacijom, ima kraći poliA-rep. Rezultat je povećan broj kopija virusnog genoma i povećana citotoksičnost u modificiranom adenovirusu. ${ }^{17}$ Proizveden je virus koji inficira samo stanice $s$ visokim koncentracijama proteina CPEB4 i niskim koncentracijama proteina CPEB1, odnosno kompetentni virus koji se razvija u tumorskim stanicama, a u zdravima je atenuiran. ${ }^{17}$ Aktivnost onkolitičkog virusa provjerena je na modelu karcinoma gušterače in vitro, a kontrola rasta tumora promatrana je na mišjim modelima. ${ }^{16}$

Rezultati su pokazali da onkolitički virus ulazi u tumorske stanice $s$ povišenom ekspresijom proteina CPEB4 i tamo se replicira, zatim izlazeći iz stanice uništava tumorsku stanicu i oslobađa veći broj virusnih čestica koje imaju potencijal zaraze drugih tumorskih stanica. ${ }^{16}$ 


\section{Zaključak}

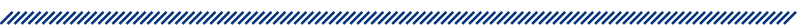

Ukupno gledano, primjena onkolitičkih virusa pruža mnoge mogućnosti, ali nosi i određene opasnosti. Zaražavanje netumorskih stanica ili nemogućnost izbjegavanja imunosnog odgovora domaćina kod slabo infektivnih ili potencijalno nepatogenih uzročnika za ljude potrebno je detaljno istražiti.

Osim toga, početak razvoja ovakvih terapijskih protokola uključuje izbor adekvatnih mikroorganizma, što predstavlja složen proces jer neki od njih dugoročno ostaju u ljudskom tijelu, što može imati i negativne posljedice.

No iako je izazova još mnogo, onkolitički su virusi obećavajuće oruđe za razvoj specifičnih, ciljanih terapija za liječenje malignih tumora.

\section{Referencije}

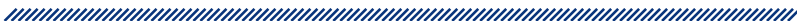

1. World Health Organization (WHO). Dostupno na: https:// www.who.ing

2. Cooper GM, Hausman RE. Stanica. Molekularni pristup, 5. izdanje, Zagreb, Medicinska naklada, 2010.

3. Andreis A, Batinić D, Čulo F, Grčević D, Lukinović-Škudar V, Marušić M, Taradi M, Višnjić D. Imunologija, 7. izd. Zagreb, Medicinska naklada, 2010.

4. Turnpenny P, Ellard S. Emeryjeve osnove medicinske genetike, 14. izd. Zagreb, Medicinska naklada, 2011.

5. Labar B, Hauptmann E i sur. Hematologija, 4. izd. Zagreb, Školska knjiga, 2007.

6. Chiocca EA, Rabkin SD. Oncolytic viruses and their application to cancer immunotherapy. Cancer Immunol Res. 2014 Apr; 2(4): 295-300. doi: 10.1158/2326-6066.CIR-14-0015.

7. Kelly E, Russel SJ. History of Oncolytic Viruses: Genesis to Genetic Engineering 2007. Dostupno na: https:// www.cell.com (pristupljeno 17.6.2017.), doi:10.1038/ mt.sj.6300108.

8. Chakradhar S. Viral vanguard: Designing cancer - killing viruses to chase metastatic tumors. Nature medicine. 2017; (23): 652-655. Dostupno na: https://www.nature. com (pristupljeno 17.6.2017.).

9. International virotherapy center. Dostupno na: https:// rigvir.com

10. Sunway Biotech. Dostupno na: https://www.sunwaybio. com.cn

11. Stojdl, DF, Lichty B, Knowles S, Marius R, Atkins H, Sonenberg N, Bell JC. Exploiting tumor-specific defects in the interferon pathway with a previously unknown oncolytic virus. Nature Medicine. 2000; (6): 821-825. Dostupno na: https://www.nature.com (pristupljeno 17.6.2017.).

12. The Preston Robert Tisch Brain Tumor Center. Dostupno na: https://tischbraintumorcenter.duke.edu

13. Brooks GF, Caroll KC, Butel JS, Morse SA, Mietzner TA. Jawetz, Melnick and Aleberg's Medical Microbiology, 26. izd. SAD, McGraw-Hill Education, 2013.

14. Mlinarić Galinović G, Ramljak Šešo M. Specijalna medicinska mikrobiologija i parasitologija, Zagreb, Merkur A.B.D. 2013.

15. Tršan $\mathrm{T}$, Vuković $\mathrm{K}$, Filipović $\mathrm{P}$, Lesac Brizić $\mathrm{A}$, Lemmermann NAW, Schober K i sur. Cytomegalovirus vector expressing RAE- $1 \gamma$ induces enhanced anti-tumor capacity of murine CD8+ T cells. Eurpean Journal of Immunology. 2017; 47(8): 1-14.

16. Institute for research in biomedicine. Dostupno na: https://www.irbbarcelona.org

17. Villanueva E, Navarro P, Rovira-Rigau M, Sibilio A, Méndez R, Fillat C. Translational reprogramming in tumor cells can generate oncoselectivity in viral therapies. $\mathrm{Na}$ ture Communications. 2017; 8: 14833; 1-9. Dostupno na: https://www.nature.com/naturecommunications 


\section{ONCOLYTIC VIRUSES}

\section{Abstract}

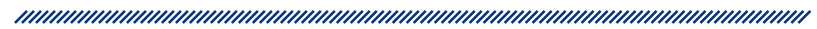

Malignant tumors are the most common cause of mortality in humans. Accumulation of mutation in cells causes uncontrolled cell division as well as prevention of their programmed cell death, leading to neoplastic changes. Tumor mass which avoids the immune response of the host, grows and spreads. Modern approach to malignant tumor therapy, which is still in the research stage, is based on the use of genetically modified bacteria and/or viruses. They are used for promotion of the chemotactic effect or production of the receptors that will be recognized by the immune system of the host and in this way stimulate the effector part of the body's defense system to destroy the tumor mass. This paper summarizes the most recent methods in the field.

Keywords: genetic engineering, oncolytic viruses, malignant tumor 